\title{
Acceptability and adoption of clinical practice guidelines and treatment protocols on preeclampsia/ eclampsia in the Dominican Republic*
}

\author{
Andelys De la Rosaํ, José Mordan², Indiana Barinas ${ }^{1}$, Mayra Toribio², Diana Mancebo ${ }^{1}$, Alexandra \\ Rodríguez ${ }^{3}$ and Mar Pacheco-Herrero 4
}

Suggested citation De La Rosa A, Mordan J, Barinas I, Toribio M. Mancebo D, Rodríguez A, et al. Acceptability and adoption of clinical practice guidelines and treatment protocols on preeclampsia/eclampsia in the Dominican Republic. Rev Panam Salud Publica. 2021;45:e8. https://doi.org/10.26633/RPSP.2021.8

ABSTRACT Objective. Estimate the acceptability and adoption by health care workers of clinical practice guidelines and treatment protocols for women with preeclampsia/eclampsia and identify the facilitating factors and barriers to their implementation.

Methods. A qualitative study was conducted, using semi-structured interviews and focus groups in five maternity hospitals. Interviews were compiled for analysis, and barriers and facilitators were characterized.

Results. Seventy health professionals (52 female and 18 male) participated, representing different levels of the health system. The majority of workers and managers were aware of the existence and content of clinical practice guidelines (CPGs) for preeclampsia/eclampsia, especially the participants with more time in the health service. With respect to facilitating factors, both medical and nursing staff were positive about continued development and implementation of high-quality CPGs. There was consensus that limitations exist, especially with respect to a lack of the necessary medicines, supplies, and equipment to meet and implement the established recommendations.

Discussion. The results of the study show the need to strengthen strategies that help close the gap between research and public policy. Studies suggest that research should focus on users, policymakers, and decisionmakers in the health system. The actors in the Dominican health system recognize the GRADE methodology as an appropriate instrument for the development and implementation of CPGs. Implementation barriers require systemic and comprehensive approaches.

Keywords $\quad$ Practice guideline; protocols; patient acceptance of health care; health policy; Dominican Republic.

Efforts to provide health systems with resources to improve the delivery of clinical services have facilitated the development of directives known as clinical practice guidelines (CPGs), treatment protocols, and evidence-based clinical standards that provide solid evidence of the effectiveness, safety, and cost of health interventions (1).

The quality of the methodological instruments used in the development of clinical practice guidelines and directives

\footnotetext{
* Official English translation from the original Spanish manuscript made by the Pan American Health Organization.

In case of discrepancy, the original version shall prevail. Access to original manuscript: https://doi.org/10.26633/RPSP.2020.163

1 Ministry of Public Health and Social Welfare, Dominican Republic. $\triangle$ Andelys

De la Rosa, andelysdelarosa@gmail.com
}

\footnotetext{
$\begin{array}{ll}2 & \text { Independent consultants. } \\ 3 & \text { Pan American Health Organization, Dominican Republic. }\end{array}$

4 Pontífica Universidad Católica Madre y Maestra, Santiago de los Caballeros, Dominican Republic.
} 
in the health field depends on the systematization of scientific information and the adoption of explicit parameters aimed at contributing solid evidence to support the recommendations. The GRADE methodology includes a systematic review of the literature and proposes the formulation of evidence tables and profiles. It is a tool that has been adopted and promoted by the Pan American Health Organization (PAHO), academia, and prestigious research and publishing organizations worldwide $(2,3)$.

The promotion of evidence-based guidelines developed through the GRADE methodology has led the health systems of Latin America and the Caribbean to invest technical and financial resources in programs to develop CPGs, directives, and treatment protocols with firm support from $\mathrm{PAHO}$, in partnership with research centers and teams of local experts organized by clinical specialty (2). The Dominican Republic has also joined in improving the quality of its CPGs by training teams of human resources in the development or adaptation of CPGs, with significant results in maternal and child care-especially, in the prevention and treatment of maternal morbidity from preeclampsia and care for premature newborns. Efforts have been underway to introduce and maintain strategies for the control and treatment of morbidity from preeclampsia/eclampsia, the country's most widespread pathology in terms of maternal complications and mortality. These include increasing prenatal check-ups, gradually training more specialists in the field of obstetrics, installing maternal intensive care units, and improving outcomes through emergency obstetric care-actions that have yielded only partial and inadequate results. Improvement continues to pose a challenge to the health system.

The data point confirming this is the reported maternal mortality ratio of 104 deaths per 100000 live births.

Preeclampsia/eclampsia is the most common cause of maternal mortality in the country. This justifies stronger action to support implementation of the CPGs, especially guidelines based on the best evidence and that have been best accepted and adopted by the services and organizations of the health system (4). In 2019, 171 maternal deaths were reported, with no indication of the maternal mortality ratio.

Research on implementation of the CPGs and treatment protocols took place in the context of the transition of the Coordinating Unit for Guidelines and Protocols to a national program, a process that would facilitate a wider territorial scope and the development of local competencies to support the quality-of-care agenda. To meet this goal, it was determined that there was a need to compile the scientific information necessary for analyzing barriers to implementation.

The Dominican health system has undergone structural changes: separation of functions; expansion of the Dominican social security system; and priority-based policy-making, including the need to protect the most vulnerable population, provide special care for sexual and reproductive health problems, and prevent maternal and child mortality $(5,6)$.

Research on implementation of the recommendations issued by the health programs is critical in order for countries to improve health and health systems, especially low- and middleincome countries. PAHO proposes this collaborative approach, facilitated by the Embedded Implementation Research initiative, as an innovative model that directly involves both health policymakers as investigators and local team leaders. The objective is to ensure that when making decisions in the health field, they have primary information that will enable them to identify and study factors related to the context and determinants of the implementation of health interventions, policies, and programs (7).

In the most sensitive areas of care, such as those related to maternity and child development, it is critical to explore the factors that determine the acceptability and adoption of CPGs and treatment protocols-in particular, the context and organization of maternal and child care services, the knowledge of health providers, perceptions of the quality of standards, the importance and relevance of clinical guidelines, technological factors, financial resources, and customary practices, among other components that affect implementation.

The main objective of this study is to estimate the degree of acceptability and adoption of CPGs and treatment protocols for women with preeclampsia/eclampsia by health care providers and to identify the facilitating factors and barriers perceived by the actors involved in the development of these guidelines and protocols.

\section{MATERIALS AND METHODS}

This study was conducted under an initiative by PAHO and the Alliance for Health Policy and Systems Research (World Health Organization) to promote implementation of health interventions to further the agenda promoting universal health coverage and the Sustainable Development Goals (8). The study employed a qualitative design in which observational information was collected. Furthermore, the work was done strategically, meaning that, in practical terms, the objective of the policy implementation process was to translate the recommendations contained in the CPGs into everyday clinical practice.

The techniques employed were semi-structured interviews and focus groups in the five national maternity referral hospitals that see the greatest number of maternal mortality cases. Three of these were teaching hospitals, where there is a greater tendency to apply knowledge and CPGs. The selected institutions were: Maternidad de Los Mina, in Santo Domingo (the country's capital), with 10921 births per year; Maternidad René Klan, in Santiago Province, the province with the second largest population in the Dominican Republic, with 7380 births; Maternidad Juan Pablo Pina de San Cristóbal, in the country's southwestern region, with 4584 births; Maternidad Jaime Sánchez, in Barahona Province (the area bordering Haiti), with 3986 annual births; and Hospital Antonio Musa de San Francisco de Macorís, located in the northeastern region of the country. The perspectives of the 70 providers were obtained in 2018.

The participants consisted of 23 nurses, 12 obstetricsgynecology (OB-GYN) residents, 12 OB-GYNs, 10 health managers, and two senior policymakers, for a total of 52 female and 18 male participants.

The study covered different levels of the health system and included authorities, decisionmakers, policymakers and staff from health administration agencies of different levels of complexity, managers of maternity services, and clinicians and workers responsible for implementing the recommendations at the most direct levels. These latter were selected for the study due to the importance of representing the people responsible for health policy implementation. 
The study consisted of a qualitative analysis of the perspectives and opinions of key actors, organized by these dimensions: acceptability, adoption, barriers, facilitators, and determinants of the health system. These dimensions were centered on several analytical categories that included the degree to which documents were disseminated, the quality of CPG and protocol development processes, professional level, years of professional training, leadership, perception of the quality of documents, factors in the health system that influence adoption, and existing barriers.

The interview content, discussion groups, dimensions addressed, and use of the instruments in the field were organized by three independent investigators who were given an introduction to the study topic and trained in the instruments.

The transcripts of the interviews and focus groups were analyzed both manually and with the Atlas $\mathrm{ti}^{\circledR}$ program, using a content analysis framework with information categorized and coded according to the dimensions originally proposed in the design of the instruments and with the inclusion of emerging categories, as appropriate.

This study was approved by the National Health Bioethics Board of the Dominican Republic (CONABIOS) and the PAHO Ethics Review Committee (PAHOERC). A standard informed consent procedure was designed in which each study subject was informed and consulted and agreed to participate. The consent form was digitized and saved.

Mexico's School of Public Health and PAHO provided support for conducting the research.

\section{RESULTS}

Information was obtained from five maternal and child centers (Maternidad Nuestra Señora de Alta Gracia, Maternidad De Los Mina, Maternidad René Klan, Maternidad Juan Pablo Pina de San Cristóbal, and Maternidad Jaime Sánchez Maternidad). The participants were divided into four focus groups. During the same period, the perspectives of the 70 providers were obtained.

\section{Characteristics of focus group members and interviewees}

The participants consisted of 23 nurses, 12 OB-GYN residents, 12 OB-GYNs, 10 health managers, and two senior policymakers, for a total of 52 female and 18 male participants.

\section{Knowledge, acceptability, and adoption}

Under the heading of knowledge about the existence of the treatment protocols and CPGs for the care of women with preeclampsia/eclampsia, the participants displayed a command of their contents. This was more evident among those with more time in service. Physicians in academic institutions were more amenable to accepting CPGs. Furthermore, the professionals assigned to teaching hospitals (three of the hospitals evaluated) had a greater knowledge of CPGs. These hospitals favor the adoption of these guidelines.

The OB-GYN specialists and residents pointed out the contents they considered key in these technical documents and indicated greater consultation of CPGs and treatment protocols than did providers in hospitals with no teaching activity.

\section{Facilitators of the CPG/protocol development process}

The majority of participants had a positive view of developing and updating CPGs with the GRADE methodology. This perception was most often found in the hospitals with medical residency programs. The participants were found to be open to the concept of evidence-based medicine and to view it positively as a basic tool for the development of CPGs and treatment protocols.

Nurses and physicians in the five hospitals were in agreement about applying CPGs and treatment protocols to women with preeclampsia/eclampsia, sometimes for reasons of a legal nature. Some of the actors viewed CPGs and protocols as compulsory regulatory measures issued by the health authority. As coercive rules, they were adopted more readily.

\section{Perceived barriers to the development process}

When delving further into the topic, comments emerged about the presence of younger professionals alongside specialists with more time in practice and who are also opinionmakers and educators but who resist embracing this type of health care and using evidence-based recommendations. One obstetrician in a focus group said, "There is often resistance on the part of staff with longer time in service", who hold the view that "what I used to do is right and I will keep on doing it".

The opinions obtained from nurses and physicians in the focus groups coincided on the presence of barriers to compliance with standards and to implementation of evidence-based recommendations for the care of women with preeclampsia/ eclampsia in CPGs and protocols, especially due to lack of the necessary drugs, supplies, and equipment. The participants noted that these constraints forced them to resort to institutional hospital practices.

It should be noted that in hospitals and in interviews with key actors in the health system, it was emphasized that there is a need to generate evidence at the national level to address preeclampsia/eclampsia so that, in the future, this can serve as the foundation for recommendations on national CPGs and protocols, which are currently based only on international evidence.

Concerning resistance to adopting CPGs and treatment protocols for ideological or religious reasons, resistance on religious grounds was noted in only one hospital-related to the indication of therapeutic abortion for patients with severe preeclampsia in the early stages of pregnancy.

It is important to note, in the opinion of the managers interviewed, implementation of CPGs and protocols is a challenge for the Dominican health system that should be addressed without delay and that should be considered in all policy documents.

Managers believe that the health system has the administrative capacity to implement CPGs. They also believe that progress must be made in the institutional strengthening of CPG implementation and that there must be movement toward a national program of guidelines and protocols that can take up the challenges identified in this study. The perception of the senior policymakers was related to the strengths derived from providing training in the GRADE methodology and including 
expert clinical and methodological advisors in the production and implementation of CPGs.

There was disagreement among the participants regarding dissemination. While some stated a preference for the digital format, especially apps for mobile devices, others indicated that they had never accessed materials this way and used paper forms. The two groups agreed about the usefulness of short forms.

Likewise, one group believed that dissemination was sufficient, while the other said it should be improved. This latter group suggested using mass media (social media and television in hospitals) and including CPGs and protocols in university undergraduate and graduate programs. This includes the related health programs (medicine, nursing, specialization in obstetrics) and medical residency programs (obstetrics and gynecology, emergency medicine, and family and community medicine).

The same applies to consideration of the need for and benefits of disseminating the guidelines to patients. One group believed this should not be done, while others advocated for it. The latter group suggested a simpler adapted model that patients and users can understand. As for implementation, the participants indicated the need to strengthen the institutional mechanisms that motivate and oblige those involved in the care process to implement CPGs and treatment protocols. Their suggestions included strengthening the leadership of hospital directors and chiefs of service; forming hospital teams to monitor implementation of CPGs and protocols, with an adequate plan for continuous improvement; establishing consequences for non-compliance with CPGs and protocols; and designing measures to prevent failure to observe or comply with the recommendations contained in CPGs.

\section{DISCUSSION}

Actors in the Dominican health system consider the GRADE methodology to be an appropriate instrument for the development of CPGs. The barriers noted are seniority in service and not being assigned to teaching hospitals. This study's findings offer resources to promote a policy to expand the structure of CPG development nationally, under a national program that supports human resource competencies and methodological resources for the production of documents informed by the best available evidence. The Dominican Republic has seen qualitative changes with the use of methodological resources for the development of GRADE guides that put us on a path to implementing a national clinical guidelines program.

Future health system challenges include the need for reference instruments informed by contextualized and replicable evidence-based research that, in turn, supports policies, programs, and interventions to promote implementation.

Different currents in the health field promote the development of innovative research models to evaluate policy and program implementation with the participation of public administrators and decisionmakers who impact the health systems (7).

The results of our study reveal the need to strengthen strategies that will help close the gap between research and public policy, focusing largely on the translation, synthesis, and exchange of knowledge. New areas of investigation serve as the basis for research on prioritizing care for users, involving patients, providers, policymakers, and decisionmakers in the health system (9). There is growing consensus on the importance of involving stakeholders on the premise that the joint design and coproduction of research have the potential to better align science with policy and thus reduce wasted research. Research that evaluates program implementation is increasingly used to identify common implementation problems and key barriers that affect efficient access to health interventions. This is backed by the findings of this study, in which users and policymakers identified the main gaps that hinder full implementation of CPGs and treatment protocols for preeclampsia/eclampsia in the country.

The results of our study apply to the Dominican situation; the research on interventions to implement CPGs concludes that there is no clear single strategy and that the resulting effect is minor $(10,11)$. These findings serve as motivation to search for new, impactful strategies focused on producing organizational changes in the structure of services and implementation of guidelines, without losing sight of the individual factors that characterize the perceptions, knowledge, and practices of health care providers. In terms of experience in Latin America, Chile's CPG program model began with research on implementation that identified the need for documents on methodological resources, the functions of actors, the role of institutions of higher education, coordination with the institutions that develop the guidelines, and an implementation strategy (9).

The perception that the GRADE methodology is both an appropriate and complex tool poses a challenge for understanding the technical structure of CPGs. The participation of senior policymakers from different sectors in the process was considered positive - especially the Ministry of Public Health's leadership in the development of CPGs and protocols and the contributions of the members from hospitals and specialized societies.

PAHO technical collaboration played an important part in the implementation and monitoring of CPG development in the country. However, greater participation by actors from the provinces is suggested, as well as more active participation by independent professionals, academia, investigators, and health system institutions. One aspect that should be noted is the participants' perceptions regarding the system's financial and technological constraints in implementing CPG recommendations.

Financing. The World Health Organization's Alliance for Health Policy and Systems Research, together with the Pan American Health Organization (PAHO), granted subsidies for research on the implementation of health programs in several Latin American and Caribbean countries through the iPIER program (Improving Program Implementation through Embedded Research). This study was declared the winner of the grant in the Dominican Republic.

Authors' contribution. AdlR contributed to the design, data analysis, interpretation, and production of the first and subsequent drafts of the article; JM provided support for the design, data analysis, interpretation, and production of the first and subsequent drafts of the article; IB, DM, and MT contributed 
to the data collection process; MPH and AR contributed with the final review of this article.

Conflict of interests. None declared by the authors.
Disclaimer. Authors hold sole responsibility for the views expressed in the manuscript, which may not necessarily reflect the opinion or policy of the RPSP/PAJPH or the Pan American Health Organization (PAHO).

\section{REFERENCES}

1. Institute of Medicine. Finding what works in health care: standards for systematic reviews. Washington, D.C.: The National Academies Press; 2011

2. Pan American Health Organization. Strengthening national evidence-informed guideline programs. A tool for adapting and implementing guidelines in the Americas. Washington D.C.: PAHO; 2018.

3. World Health Organization. WHO handbook for guideline development, 2nd ed. Geneva: WHO; 2015.

4. Ministerio de Salud Pública, Dirección de Epidemiología, SINAVE, República Dominicana; 2017.

5. Gobierno de República Dominicana. Ley General de Salud N. ${ }^{\circ}$ 42-01, promulgada el 8 de marzo del 2001. Available at: http:// www.sisalril.gov.do/mobile/pdf/leyes/ley_no_42-01 .pdf

6. Gobierno de República Dominicana. Ley N. ${ }^{\circ} 87-01$ que crea ElSistema Dominicano de Seguridad Social, promulgada el 9 de mayo del 2001. Available at: http://www.sisalril.gov.do/pdf/leyes/ley_no 87-01.pdf

7. Langlois EV, Mancuso A, Elias V, Reveiz L. Embedding implementation research to enhance health policy and systems: a multi-country analysis from ten settings in Latin America and the Caribbean. Health Res Policy Sy 2019;17(1):85.
8. Pan American Health Organization. 53rd Directing Council, 66th Session of the Regional Committee of WHO for the Americas. Washington, D.C., 29 September to 3 October 2014.

9. Herrera P, Fajreldin V, Rodríguez MF, Kraemer P, Mendoza C, Pineda I, et al. Guías de práctica clínica: estudio cualitativo sobre su implementación en los sistemas de salud. Rev Panam Salud Publica. 2017;41:e67.10.

10. Gagliardi AR, Brouwers MC. Integrating guideline development and implementation: analysis of guideline development manual instructions for generating implementation advice. Implementation Science. 2012;7:67.

11. Zamora G, Meneses D, De-Regil LM, Neufeld L, Pena-Rosas JP, Sinisterra OT. Considerations on the development of nutrition-related guidelines by the World Health Organization and their implementation. Arch Latinoam Nutr. 2015;65(1):1-11.

Manuscript received on 29 June 2020. Revised version accepted for publication on 6 October 2020

\section{Aceptabilidad y adopción de guías de práctica clínica y protocolos de atención sobre preeclampsia-eclampsia en la República Dominicana}

RESUMEN Objetivo. Estimar la aceptabilidad y adopción de las guías de práctica clínica (GPC) y protocolos de atención a la mujer con preeclampsia-eclampsia por parte del personal prestador de los servicios de salud, e identificar los factores facilitadores y las barreras para su implementación.

Métodos. Se desarrolló un estudio cualitativo por medio de entrevistas semiestructuradas y grupos focales en cinco maternidades. Se recopilaron las entrevistas para su análisis y se caracterizaron las barreras y facilitadores.

Resultados. Participaron 70 profesionales de la salud (52 de sexo femenino y 18 de sexo masculino) que se desempeñan en distintos niveles del sistema de salud, participaron. La mayoría de los prestadores y gerentes conocen la existencia de las GPC de eclampsia-preeclampsia y su contenido, sobre todo los participantes con más tiempo en el servicio. Para los facilitadores, se estableció una valoración positiva entre el personal médico y de enfermería ante el proceso de continuar con la elaboración e implementación de GPC de alta calidad. Hubo consenso en cuanto a la existencia de limitaciones, sobre todo, por la falta de medicamentos, insumos y equipos requeridos, para cumplir y aplicar las recomendaciones formuladas.

Discusión. Los resultados del estudio exponen la necesidad de fortalecer estrategias que ayuden a cerrar la brecha entre la investigación y la política pública. Estudios fundamentan la investigación en priorizar la atención a los usuarios, y los encargados de formular políticas y los tomadores de decisiones en el sistema de salud. Los actores del sistema de salud dominicano reconocen la metodología GRADE como un instrumento apropiado para la formulación e implementación de GPC. Las barreras de implementación requieren de abordajes sistémicos e integrales.

Palabras clave Guía de práctica clínica; protocolos; aceptabilidad de la atención de salud; políticas de salud; República Dominicana. 


\section{Aceitabilidade e adoção de diretrizes de prática clínica e protocolos de atenção para pré-eclâmpsia e eclâmpsia na República Dominicana}

RESUMO Objetivo. Estimar a aceitabilidade e a adoção de diretrizes de prática clínica (DPCs) e protocolos de atenção para mulheres com pré-eclâmpsia e eclâmpsia por profissionais da saúde e identificar os fatores facilitadores e barreiras à sua implementação.

Métodos. Desenvolvemos um estudo qualitativo baseado em entrevistas semiestruturadas e grupos focais em cinco maternidades. As entrevistas foram coletadas para análise, sendo caracterizadas as barreiras e fatores facilitadores.

Resultados. O estudo contou com a participação de 70 profissionais da saúde (52 mulheres e 18 homens) que trabalham em diferentes níveis do sistema de saúde. Em sua maioria, os profissionais e administradores estão cientes da existência de DPCs para pré-eclâmpsia e eclâmpsia e conhecem seu conteúdo, especialmente os que têm mais tempo de experiência. Em relação aos fatores facilitadores, os profissionais médicos e de enfermagem consideraram positivo o processo de elaboração e implementação de DPCs de alta qualidade. Houve consenso sobre a existência de limitações, especialmente no que diz respeito à falta de medicamentos, insumos e equipamentos necessários para cumprir e implementar as recomendações.

Discussão. Os resultados do estudo deixam clara a necessidade de reforçar as estratégias que ajudam a estabelecer vínculos entre a pesquisa e as políticas públicas. A pesquisa futura deve priorizar a atenção aos usuários e o apoio aos decisores e responsáveis pela elaboração de políticas no sistema de saúde. Os atores do sistema de saúde dominicano reconhecem a metodologia GRADE como um instrumento apropriado para a formulação e implementação de DPCs. As barreiras à implementação exigem abordagens sistêmicas e abrangentes.

Palavras-chave Guia de prática clínica; protocolos; aceitação pelo paciente de cuidados de saúde; política de saúde; República Dominicana. 